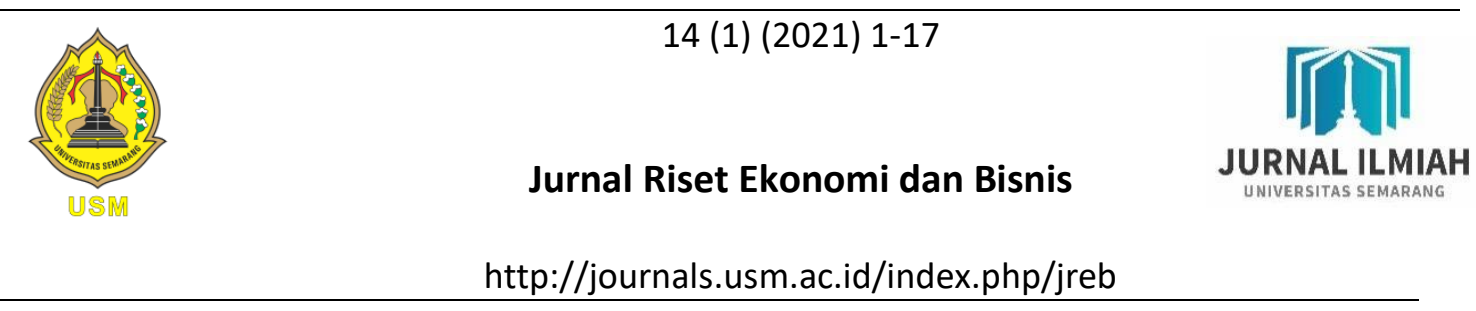

\title{
PERAN PROFITABILITAS SEBAGAI VARIABEL INTERVENING PADA PENGARUH LIKUDITAS, DER DAN SIZE TERHADAP RETURN SAHAM INDEKS SRI KEHATI
}

\author{
Tito Rahardian ${ }^{1)}$; Hersugondo ${ }^{2)}$ \\ titorahardian@ @students.undip.ac.id ${ }^{1)}$; hersugondo@ lecturer.undip.ac.id ${ }^{2)}$ \\ Program Studi Manajemen, Universitas Diponegoro, Semarang, Indonesia
}

\begin{abstract}
Info Artikel
Sejarah Artikel:

Diterima : 02-01-2020

Disetujui : 26-04-2021

Dipublikasikan: 30-042021

Keywords:

Likuidity; stock Returns ;company size; Debt to equity; return on asset
\end{abstract}

\begin{abstract}
Abstrak
Penelitian ini bertujuan untuk menganalisis pengaruh likuiditas, debt to equity ratio, dan ukuran perusahaan terhadap return saham. Populasi yang digunakan dalam penelitian ini adalah seluruh perusahaan yang terdaftar di Bursa Efek Indonesia tahun 2020. Setelah melalui metode purposive sampling terdapat 16 perusahaan yang diperoleh sebagai sampel dari indeks SRI-Kehati selama tahun 2012-2018. Teknik analisis data yang digunakan adalah analisis jalur, versi luas dari regresi linier berganda dan menggunakan alat analisis SPSS versi 23. Hasil penelitian menunjukkan bahwa current ratio dan firm size berpengaruh negatif tidak signifikan terhadap return saham, debt to equity ratio dan ROA berpengaruh positif signifikan terhadap return saham. Rasio lancar dan DER berpengaruh signifikan negatif terhadap ROA, sedangkan ukuran perusahaan berpengaruh signifikan positif terhadap ROA. Sedangkan ROA tidak berpengaruh memediasi hubungan current ratio dan debt to equity ratio terhadap return saham, tetapi ROA berpengaruh memediasi hubungan ukuran perusahaan dengan return saham.
\end{abstract}

\section{THE MODERATING ROLE OF PROFITABILITY ON THE INFLUENCE OF LIQUIDITY, DER AND SIZE}

\section{AGAINST STOCK RETURN LISTED IN THE SRI KEHATI INDEX}

\section{Abstract}

This study aims to analyze the effect of liquidity, debt to equity ratio, and firm size on stock return. Current ratio used as a proxy from liquidity and ROA were used as proxy from profitability. The population that was used in this research consisted of all listed firms in Indonesia Stock Exchange 2020. After passed the purposive sampling method there were 16 firms obtained as samples from SRI-Kehati index during 2012-2018. The data analysis technique is path analysis, the wide version from multiple linear regression. The result of this research showed that current ratio and firm size have negatively non significant impact on stock returns, debt to equity ratio and ROA have positively significant impact on stock returns. Current ratio and debt to equity ratio have a negatively significant effect on $R O A$, while firm size has positively significant impact on ROA. Meanwhile, ROA doesn't have impact on mediating relation of current ratio and debt to equity ratio to stock returns, but ROA have an impact on mediating relation of firm size to stock returns. 


\section{PENDAHULUAN}

Pasar modal adalah salah satu pasar penting yang mempengaruhi ekonomi sebuah negara. Di Indonesia, pasar modal menjadi media untuk memperoleh keuntungan baik investor maupun perusahaan. Investor bisa melakukan investasi terhadap instrumen keuangan yang diperdagangkan seperti obligasi, saham, SBI, dan lain lain. (Rizal, 2016) Return merupakan hasil yang diperoleh dari suatu investasi. Return saham ini bisa berbentuk capital gain atau deviden. Return saham yang diharapkan pasti adalah return saham yang tinggi. Terdapat beberapa indeks yang bisa dijadikan pilihan oleh investor pada Bursa Efek Indonesia dan salah satunya adalah Indeks SRI-Kehati. Indeks ini berisikan emiten-emiten yang memiliki tujuan utama pelestarian lingkungan.

Berdasarkan teori sinyal, informasi yang terdapat didalam perusahaan akan menjadi dasar bagi pihak eksternal untuk mengambil keputusan investasi terhadap perusahaan tersebut (Hartono, 2013). Beberapa informasi yang kemungkinan berpengaruh terhadap return saham adalah rasio-rasio keuangan perusahaan seperti rasio likuiditas, rasio leverage, serta rasio profitabilitas. Berikut disajikan tabel rata-rata nilai current ratio, debt to equity ratio, firm size, ROA, serta return saham perusahaan yang terdaftar dalam Indeks SRI-Kehati periode 20122018.

Tabel 1

Data Rata-Rata Variabel CR, DER, Firm Size, ROA, dan Return Saham

Perusahaan terdaftar di Indeks SRI-Kehati

Periode Tahun 2012-2018

\begin{tabular}{|l|c|c|c|c|c|c|c|}
\hline & 2012 & 2013 & 2014 & 2015 & 2016 & 2017 & 2018 \\
\hline Return Saham & 0,3238 & 0,043 & 0,3252 & $-0,2238$ & 0,2527 & $-0,0035$ & $-0,0244$ \\
\hline Current Ratio & 1,8891 & 1,5849 & 1,6271 & 1,5808 & 1,6588 & 2,0185 & 1,6664 \\
\hline Debt to Equity & 1,221 & 1,285 & 1,303 & 1,164 & 1,075 & 1,280 & 1,313 \\
\hline Ratio & & & & & & & \\
\hline Profitabilitas & 0,1346 & 0,1177 & 0,1113 & 0,0834 & 0,0927 & 0,0855 & 0,0896 \\
\hline
\end{tabular}

Sumber : $\quad$ Sumber : Output data penelitian, diolah

Pada Tabel 1 dapat dilihat bahwa return saham perusahaan terindeks di SRI-Kehati mengalami fluktuasi. Banyak faktor yang mempengaruhi fluktuasi return saham, diantaranya adalah rasio keuangan perusahaan serta faktor eksternal. Rasio likuiditas dapat diukur menggunakan rasio lancar (CR), rasio leverage (DER), rasio profitabilitas diukur dengan (ROA). Faktor eksternal dalam penelitian menggunakan firm size.

Rasio likuiditas menggambarkan kemampuan perusahaan dalam melunasi kewajiban lancarnya. (Kurniawan, Ghasarma, \& Yuliani, 2016) rasio likuiditas yang paling sering digunakan dalam melakukan analisis perusahaan adalah Rasio lancar atau Current Ratio (CR) yang diukur dengan membandingkan jumlah aktiva lancar dengan utang lancar. Mengacu pada teori sinyal, hubungan antara CR terhadap return saham adalah positif yang mana jika CR meningkat akan mengakibatkan return saham yang meningkat. (Ulupui, 2006) dalam (I. M. G. 
D. Putra \& Dana, 2016) menyatakan bahwa jika current ratio mengalami kenaikan maka akan berpengaruh terhadap kenaikan return saham Namun, pada Tabel 1 walaupun current ratio selalu mengalami peningkatan dari 2015 hingga 2017, return saham pada tahun 2017 mengalami penurunan dibanding pada tahun sebelumnya.

Rasio leverage adalah rasio yang menghitung seberapa jauh perusahaan didanai oleh hutang atau pihak eksternal dengan kemampuan perusahaan yang digambarkan sebagai ekuitas (Syafri, 2009). Berdasarkan teori signalling, hubungan DER terhadap return saham adalah negatif, ketika DER meningkat, maka return saham yang dihasilkan akan semakin rendah. Namun pada kenyataannya yang ditunjukkan oleh tabel fenomena gap pada tahun 2013 ke tahun 2014, ketika DER mengalami peningkatan, justru return saham yang dihasilkan juga mengalami peningkatan. Serta pada tahun 2015, DER mengalami penurunan namun return saham juga mengalami penurunan. Hasil penelitian (Pratiwi \& Putra, 2015) yang menunjukkan bahwa DER berpengaruh negatif terhadap return saham. Namun berbeda dengan penelitian (Lindayani \& Dewi, 2016) yang menunjukkan bahwa DER berpengaruh positif terhadap return saham.

Firm Size lazim diukur dengan menggunakan Ln (Total Aset). Semakin tinggi nilai firm size, maka semakin besar kemudahan perusahaan dalam memperoleh sumber pendanaan. (Sugiarto, 2011), kenaikan yang terjadi pada ukuran perusahaan mempengaruhi kenaikan return saham. Namun, berdasarkan data Tabel 1 menunjukkan bahwa cenderung terjadi peningkatan ukuran perusahaan dari tahun 2012-2018 namun tidak didukung dengan meningkatnya return saham yang seharusnya naik mengikuti pertumbuhan ukuran perusahaan dari tahun 2012-2018. Hasil penelitian (I. M. G. D. Putra \& Dana, 2016), (Sudarsono \& Sudiyatno, 2016) menunjukkan firm size berpengaruh positif terhadap return saham. Namun berbeda dengan penelitian (Chandra et al., 2019) yang menunjukkan pengaruh negatif dari firm size terhadap return saham.

Rasio profitabilitas ialah kemampuan perusahaan dalam memperoleh laba dalam hubungannya dengan penjualan, total aktiva, ataupun modal sendiri (Agus, 2010). Berdasarkan teori sinyal, hubungan ROA terhadap return saham ialah hubungan yang positif, artinya jika ROA mengalami peningkatan, maka return saham juga mengalami peningkatan. Namun pada kenyataannya yang ditunjukkan oleh tabel fenomena gap pada tahun 2018, ketika ROA mengalami peningkatan return saham yang dihasilkan justru mengalami penurunan. Hasil penelitian (Parwati \& Sudiartha, 2016) dan (Chandra et al., 2019) menunjukkan bahwa ROA berpengaruh positif terhadap return saham. Namun berbeda dengan penelitian (Arista \& Astohar, 2012) yang menunjukkan bahwa ROA berpengaruh negatif terhadap return saham.

Di sisi lain, rasio likuiditas juga merupakan faktor yang seringkali berpengaruh pada fluktuasi ROA. Semakin tinggi current ratio maka ROA akan semakin meningkat sesuai dengan pernyataan dari (Nursatyani, Wahyudi, \& Syaichu, 2014). Namun pada kenyataannya yang ditunjukkan oleh tabel fenomena gap pada tahun 2014 dan 2017, ketika CR mengalami peningkatan, ROA yang dihasilkan justru mengalami penurunan. Hasil penelitian (Pramesti, Wijayanti, \& Nurlaela, 2016) menunjukkan bahwa CR berpengaruh positif terhadap ROA. Namun berbeda dengan penelitian (Nursatyani et al., 2014) menunjukkan bahwa CR berpengaruh negatif terhadap ROA.

Semakin tinggi rasio DER maka ROA akan mengalami penurunan (Rosyadah, 2013). Namun pada kenyataannya yang ditunjukkan oleh tabel fenomena gap pada tahun 2018, ketika DER mengalami peningkatan, ROA yang dihasilkan juga mengalami peningkatan. Hasil penelitian Pramesti, dkk (2016) menunjukkan bahwa DER berpengaruh positif terhadap ROA. Namun berbeda dengan penelitian (Nursatyani et al., 2014) yang menunjukkan bahwa DER berpengaruh negatif terhadap ROA.

Ukuran perusahaan yang semakin besar menandakan ROA yang semakin besar pula. Kegiatan perusahaan yang semakin besar akan menghasilkan penjualan yang semakin besar 
sehingga berdampak pada meningkatnya laba serta ROA (Nursatyani, Wahyudi, \& Syaichu, 2014). Namun pada kenyataannya pada tabel 1 tahun 2012 hingga 2014 saat firm size meningkat, ROA justru mengalami penurunan. Hasil yang sama ditunjukkan pada tahun 2017 saat firm size mengalami peningkatan, ROA justru mengalami penurunan. Hasil penelitian Barus (2013) menunjukkan firm size berpengaruh positif terhadap ROA. Namun berbeda dengan penelitian (Putra \& Badjra, 2015) dan Nursatyani, Wahyudi, \& Syaichu (2014) yang menunjukkan firm size berpengaruh negatif terhadap ROA.

Berdasarkan tabel fenomena gap dan hasil penelitian terdahulu yang masih menunjukkan adanya kontradiksi hasil, maka hal tersebut yang melatarbelakangi penulis untuk meneliti kembali mengenai "Analisis Pengaruh Rasio Likuiditas, DER, Dan Firm Size Terhadap Return Saham Dengan Profitabilitas Sebagai Variabel Intervening (Studi Kasus Pada Perusahaan Yang Terdaftar Di Indeks SRI-Kehati Periode 2012-2018)”.

\section{TELAAH PUSTAKA}

\section{Teori Sinyal}

Teori sinyal dikembangkan oleh Ros pada tahun 1997. Prinsip dari signalling theory adalah adanya informasi yang beredar dari perusahaan yang dianggap sebagai sinyal atau pertanda dari kegiatan perusahaan terhadap keputusan investasi pihak eksternal perusahaan (Jogiyanto, 2013). Informasi pasar yang sangat beragam mengakibatkan timpang tindihnya informasi. Dengan kata lain, terkadang informasi yang beredar menjadi bias. Pengaruh biasnya informasi adalah kekeliruan investor dalam melakukan keputusan investasi. Hal ini dikarenakan setiap tindakan yang dilakukan mengandung informasi, dan adanya asymmetric information.

\section{Teori Pecking Order}

Pada tahun 1984, Myers mengembangkan suatu teori altematif yang dikenal sebagai pecking order theory dalarn keputusan pendanaan melalui tulisannya yang berjudul The Capital Structure Puzzle, menyatakan bahwa ada semacam tata urutan pecking order bagi perusahaan dalam keputusan pendanaan. Tata urutan pendanaan muncul jika biaya dari penerbitan sekuritas baru meliputi biaya dan manfaat dari pembayaran dividen dan penerbitan hutang. Teori pecking order ini bisa menunjukkan bahwa perusahaan yang memiliki tingkat hutang yang rendah berbanding terbalik dengan tingkat keuntungannya. Hal ini dikarenakan bahwa semakin tinggi laba dari suatu perusahaan, maka mereka tidak membuka kesempatan untuk berhutang.

\section{The Fama-French Three Factor Model}

Mengacu kepada penelitian yang dilakukan oleh Fama dan French (1992), terdapat tiga model faktor yang bisa menjadi landasan studi empiris dari tingkat pengembalian aset. Tiga faktor tersbeut merupakan beta, size yang diukur menggunakan kapitalisasi pasar serta book-tomarket ratio dalam indeks pasar yang digunakan untuk menerangkan nilai mean return. Model tiga faktor ini dikemukakan oleh Fama-French karena mereka mengungkapkan bahwa beta saham yang menjadi proksi CAPM bukan satu-satunya variabel yang bisa menentukan imbal hasil suatu saham.

\section{Analisis Du Pont}

Metode $\mathrm{Du}$ Pont dikembangkan oleh seorang teknisi pada tahun 1918 untuk menganalisis laporan keuangan perusahaan dengan pendekatan tertentu terhadap analisa rasio untuk mengevaluasi efektivitas perusahaan. Analisis ini mempunyai hubungan dalam pengembalian investasi perusahaan atau ROI dengan perkalian antara profit margin dengan Turnover of 
Operating Assets, sehingga didapatkan hasil kemampuan menghasilkan laba atas total aktiva (Horne dan Wachowicz, 2009). Menurut (Horne \& Wachowicz, 2012) ROA atau ROI merupakan rasio profitabilitas yang sering digunakan manajer keuangan untuk mengukur efektivitas keseluruhan dalam menghasilkan laba dengan aktiva yang dimiliki. Berdasarkan pendapat tersebut, maka dapat diambil bahwa faktor yang berpengaruh terhadap profitabilitas ialah laba bersih setelah pajak, penjualan bersih, serta total aset.

\section{Pengaruh CR (Current Ratio) terhadap ROA}

Nilai current ratio yang tinggi bisa mengindikasikan bahwa perusahaan mengalami kelebihan aktiva lancar (Nursatyani et al., 2014). Tingginya nilai current ratio berarti perusahaan memiliki aset lancar dengan jumlah yang besar dan menjadi aset yang menganggur. Aset lancar yang tidak digunakan dengan baik akan menurunkan profitabilitas perusahaan. Hasil ini didukung oleh hasil penelitian (Nursatyani et al., 2014) serta (Mohamad \& Saad, 2010).

H1 : Current Ratio berpengaruh negatif signifikan terhadap profitabilitas

\section{Pengaruh DER (Debt to Equity Ratio) terhadap ROA}

Coricelli, dkk (2013) dalam (Putra \& Badjra, 2015) menyatakan bahwa leverage perusahaan berpengaruh negatif terhadap profitabilitas perusahaan, karena tingkat leverage yang tinggi berisiko tinggi dengan ditandai adanya biaya hutang yang besar. Hutang perusahaan yang besar tersebut menyebabkan profitabilitas perusahaan rendah karena arus kas perusahaan difokuskan untuk melunasi hutang perusahaan. Hasil ini sesuai dengan hasil penelitian (Putra \& Badjra, 2015) serta (Rosyadah, 2013).

H2 : DER berpengaruh negatif signifikan terhadap ROA

\section{Pengaruh Firm Size terhadap ROA}

Perusahaan yang berukuran besar dari segala bidang, pasti akan memiliki pendapatan yang lebih besar pula. (Pramesti et al., 2016) menyatakan bahwa skala perusahaan yang semakin besar, maka mengakibatkan biaya yang lebih besar dalam operasional untuk menghasilkan laba yang lebih besar juga. Hal tersebut dikarenakan kegiatan operasional perusahaan yang lebih kompleks dan bisa menghasilkan penjualan yang lebih tinggi. Dengan hasil penjualan yang meningkat tersebut, maka profitabilitas akan ikut meningkat. Hasil ini sesuai dengan hasil penelitian yang dilakukan oleh Pramesti, dkk (2016) serta Barus (2013).

H3 : Firm Size berpengaruh positif terhadap ROA

\section{Pengaruh CR (Current Ratio) terhadap Return Saham}

Berdasarkan teori sinyal, perusahaan yang menunjukkan rasio CR yang tinggi merupakan sinyal bahwa perusahaan bisa memenuhi kewajiban jangka pendeknya karena adanya aset lancar yang dimiliki. Hal ini ditangkap oleh investor sebagai suatu sinyal positif karena semakin baik kemampuan perusahaan dalam menjaga kinerja perusahaannya. Hal ini meyakinkan investor untuk menginvestasikan dananya pada saham perusahaan tersebut, sehingga berpotensi meningkatkan permintaan saham perusahaan, peningkatan permintaan saham tentu akan berdampak pada peningkatan return saham yang diperoleh investor. Hal ini didukung oleh penelitian (Dewi, 2017) serta (Parwati \& Sudiartha, 2016) yang menunjukkan bahwa CR berpengaruh positif terhadap return saham.

H4 : CR (Current Ratio) berpengaruh positif terhadap Return Saham 


\section{Pengaruh DER (Debt to Equity Ratio) terhadap Return Saham}

Berdasarkan teori sinyal, hubungan DER terhadap return saham adalah hubungan yang negatif, yaitu jika DER meningkat akan menurunkan return saham. Hal ini ditangkap oleh investor sebagai suatu sinyal yang negatif sehingga investor menghindari perusahaan dengan DER yang tinggi. Namun, menurut teori pecking order, pemanfaatan modal eksternal yang efektif bisa menghasilkan peningkatan profitabilitas dikarenakan penjualan yang meningkat. Profitabilitas yang meningkat akan berdampak pada meningkatnya return saham. Sehingga, DER bisa berdampak positif pada return saham. Hal ini didukung oleh hasil penelitian (Lindayani \& Dewi, 2016) dan (Kennedy \& Angriawan, 2015) yang menunjukkan bahwa DER berpengaruh positif terhadap return saham.

H5 : DER (Debt to Equity Ratio) berpengaruh positif terhadap Return Saham

\section{Pengaruh Firm Size terhadap Return Saham}

Berdasarkan teori model tiga faktor Fama-French (1992), firm size berpengaruh negatif terhadap return saham. Return saham perusahaan yang telah direalisasi bisa dipengaruhi oleh ukuran perusahaan. Perusahaan yang berukuran kecil maka return saham semakin tinggi, serta sebaliknya perusahaan yang berukuran besar akan memiliki return saham yang rendah. Perusahaan yang semakin besar akan mendiversifikasikan pendapatannya semakin luas. Karena perusahaan memiliki bidang yang beragam, maka aset yang dialokasikan untuk meningkatkan produktivitas juga akan semakin besar serta merata. Lain halnya dengan perusahaan berukuran kecil, jika mendapatkan bidang yang perlu ditingkatkan, maka alokasi dana perusahaan bisa dimaksimalkan pada bidang tersebut, sehingga profitabilitas meningkat serta berdampak pada meningkatnya return saham. Hasil ini didukung oleh hasil penelitian (Santa \& Muharam, 2015), (Chandra et al., 2019), serta (Raningsih \& Putra, 2015).

H6 : Firm size berpengaruh positif terhadap return saham

\section{Pengaruh ROA terhadap Return saham}

Menurut signalling theory, hubungan ROA terhadap return saham adalah hubungan yang positif, yaitu jika ROA mengalami peningkatan, maka return saham juga akan mengalami peningkatan. Keuntungan yang diperoleh tersebut bisa berpengaruh terhadap return saham (Rosanti, 2018.). Return on asset yang meningkat akan menjadi indikator yang dipertimbangkan oleh investor. Hal ini menyebabkan banyak investor yang menginvestasikan uangnya menjadi saham sehingga harga saham perusahaan tersebut meningkat. Jika harga saham meningkat, maka return saham perusahaan akan meningkat. Hasil ini sesuai dengan hasil penelitian yang dilakukan oleh (Putra \& Dana, 2016), (Chandra et al., 2019), serta (Dewi, 2017).

H7 : ROA berpengaruh positif terhadap return saham

\section{Pengaruh CR (Current Ratio) terhadap Return Saham dengan ROA (Return on Asset) sebagai variabel mediasi}

Mengacu pada signaling theory dimana pihak-pihak internal perusahaan berupaya memberikan informasi terkait fundamental perusahaan, operasional perusahaan kepada investor untuk membuat keputusan investasi. Hal ini berkaitan dengan signaling theory dimana pihak-pihak internal perusahaan berupaya memberikan informasi terkait fundamental perusahaan, operasional perusahaan kepada investor untuk membuat keputusan investasi. Hasil ini sesuai dengan penelitian yang dilakukan oleh (Kurniawan et al., 2016)

H8 : ROA (Return on Asset) memediasi hubungan antara CR (Current Ratio) dan Return Saham. 


\section{Pengaruh DER (Debt to Equity Ratio) terhadap Return Saham dengan ROA (Return on}

Asset) sebagai variabel mediasi

Financial leverage menjelaskan perbandingan antara jumlah utang terhadap jumlah ekuitas perusahaan (Kurniawan et al., 2016). Seluruh keputusan investasi bertujuan akhir peningkatan net income, sehingga ROA diharapkan meningkat (Kurniawan et al., 2016). Jika perusahaan bisa mengalokasikan hutang baik jangka pendek maupun panjang secara efektif, maka peningkatan ROA perusahaan merupakan suatu hal yang mudah dicapai. Peningkatan ROA akan berdampak pada meningkatnya return saham sesuai dengan signalling theory. Hasil ini sesuai dengan hasil penelitian (Pramesti et al., 2016) yang dimana DER berpengaruh positif terhadap ROA.

H9 : Profitabilitas berpengaruh dalam memediasi pengaruh DER terhadap return saham.

\section{Pengaruh Firm Size terhadap Return Saham dengan ROA (Return on Asset) sebagai variabel mediasi}

Ukuran perusahaan yang semakin besar akan mengakibatkan meningkatnya jumlah produksi dan berefek pada meningkatnya penjualan serta profitabilitas yang diperoleh perusahaan. Profitabilitas tersebut menjadi sinyal baik bagi investor. Sinyal baik tersebut direspon investor dengan naiknya permintaan saham yang berujung peningkatan harga saham, dan akhirnya menyebabkan meningkatnya return saham perusahaan. Hasil ini sesuai dengan hasil penelitian yang dilakukan oleh (Riawan, 2019) yang menemukan bahwa ROA berpengaruh memediasi pengaruh firm size dan return saham.

H10 : Profitabilitas berpengaruh dalam memediasi pengaruh Firm size terhadap return saham.

\section{METODE PENELITIAN}

Metode penelitian menggunakan pendekatan kuantitatif dengan data sekunder yang diperoleh dari website www.idx.com serta laboratorium Bloomberg dalam mencari data penelitian. Data historis tersebut dikumpulkan dalam rentang waktu pengamatan dari tahun 2012-2018. Alat analisis yang digunakan adalah SPSS versi 23 untuk windows. Populasi dalam penelitian ini adalah seluruh perusahaan yang terdaftar dalam Bursa Efek Indonesia periode 2012-2018. Sampel penelitian dipilih dari seluruh populasi dengan menggunakan metode purposive sampling. Sehingga diperoleh beberapa perusahaan dalam Indeks SRI-Kehati.

\section{Definisi Operasional dan Pengukuran Variabel}

Pada penelitian ini menjelaskkan mengenai tiga variabel independen yaitu current ratio, debt to equity ratio, serta firm size dan juga variabel intervening yaitu return on asset. Adapun variabel dependen yang digunakan dalam penelitian ini adalah return saham. Berikut adalah penjelasan mengenai variabel yang digunakan dalan penelitian ini. 
Tabel 2. Definisi Operasional dan Pengukuran Variabel

\begin{tabular}{|c|c|c|c|c|}
\hline Variabel & $\begin{array}{c}\text { Definisi } \\
\text { Operasional }\end{array}$ & Pengukuran & Skala & Referensi \\
\hline $\begin{array}{l}\text { Rasio } \\
\text { Likuiditas } \\
\text { (Current } \\
\text { Ratio) (X1) }\end{array}$ & $\begin{array}{l}\text { Kemampuan } \\
\text { perusahaan untuk } \\
\text { melunasi } \\
\text { kebutuhan } \\
\text { hutangnya pada } \\
\text { saat jatuh tempo }\end{array}$ & Current Ratio $=\frac{\text { Aset Lancar }}{\text { Utang Lancar }} \times 100 \%$ & Rasio & $\begin{array}{l}\text { Fahmi, } \\
2011\end{array}$ \\
\hline $\begin{array}{l}\text { Debt to } \\
\text { Equity Ratio } \\
\text { (DER) (X2) }\end{array}$ & $\begin{array}{l}\text { Adalah } \\
\text { penggunaan } \\
\text { biaya tetap untuk } \\
\text { meningkatkan } \\
\text { (naik level) } \\
\text { profitabilitas }\end{array}$ & DER $=\frac{\text { Total Hutang }}{\text { Total Ekuitas }} \times 100 \%$ & Rasio & $\begin{array}{l}\text { Horne \& } \\
\text { Wachowicz } \\
\text { Jr, } 2012\end{array}$ \\
\hline $\begin{array}{l}\text { Ukuran } \\
\text { Perusahaan } \\
\text { (X3) }\end{array}$ & $\begin{array}{l}\text { Besar kecilnya } \\
\text { suatu perusahaan } \\
\text { yang ditunjukkan } \\
\text { atau dinilai } \\
\text { dengan total aset, } \\
\text { total penjualan, } \\
\text { total laba, beban } \\
\text { pajak dan lain- } \\
\text { lain }\end{array}$ & Firm Size $=L_{n}$ Total Aset & Rasio & $\begin{array}{l}\text { Brigham \& } \\
\text { Houston, } \\
2010\end{array}$ \\
\hline $\begin{array}{l}\text { Return } \\
\text { Saham (Y) }\end{array}$ & $\begin{array}{l}\text { Adalah } \\
\text { pengembalian } \\
\text { yang diperoleh } \\
\text { dari investasi }\end{array}$ & Return Saham $=\frac{P t-(P t-1)}{P t-1} \times 100 \%$ & Rasio & $\begin{array}{l}\text { Hartono, } \\
2013\end{array}$ \\
\hline $\begin{array}{l}\text { Rasio } \\
\text { Profitabilitas } \\
\text { (Return of } \\
\text { Aset) (Z) }\end{array}$ & $\begin{array}{l}\text { Kemampuan } \\
\text { masing-masing } \\
\text { perusahaan untuk } \\
\text { memperoleh laba } \\
\text { atau tolok ukur } \\
\text { efektivitas } \\
\text { perusahaan } \\
\text { dalam mengelola } \\
\text { manajemen }\end{array}$ & $R O A=\frac{\text { Pendapatan setelah Pajak }}{\text { Total Aset }} \times 100 \%$ & Rasio & $\begin{array}{l}\text { Wiagustini, } \\
\text { 2010: } 77\end{array}$ \\
\hline
\end{tabular}




\section{HASIL PENELITIAN DAN PEMBAHASAN}

\section{Statistik Deskriptif}

Tabel 3

Statistik Deskriptif

\begin{tabular}{|l|r|r|r|r|r|}
\hline & \multicolumn{1}{|c|}{$\mathrm{N}$} & \multicolumn{1}{c|}{ Minimum } & Maximum & \multicolumn{1}{c|}{ Mean } & Std. Deviation \\
\hline Stock Return & 112 &,- 59 & 2,03 &, 1061 &, 41514 \\
Liquidity & 112 &, 38 & 5,21 & 1,6691 &, 97294 \\
DER & 112 &, 16 & 5,67 & 1,2344 & 1,08633 \\
Firm Size & 112 & 27,68 & 33,11 & 30,7298 & 1,26257 \\
Profitability & 112 &, 00 &, 48 &, 1067 &, 10018 \\
Valid N (listwise) & 112 & & & & \\
\hline
\end{tabular}

Sumber : Output data penelitian, diolah

Berdasarkan hasil perhitungan pada tabel diatas dapat dianalisis sebagai berikut :

a) Rata-rata Return saham perusahaan indeks SRI-Kehati selama periode penelitian sebesar $0,1061 \%$. Nilai return saham terendah adalah sebesar $-0,59 \%$ oleh PT Timah Tbk pada tahun 2015 dan tertingginya adalah 2,03\% oleh PT Adhi Karya pada tahun 2012.

b) Rata-rata CR perusahaan indeks SRI-Kehati selama periode penelitian sebesar 1,6691\%. Nilai tertinggi CR adalah sebesar 5,21\% dimiliki PP London Sumatera Tbk tahun 2017. Serta nilai terendah CR dimiliki 0,38\% dimiliki PT Jasa Marga Tbk tahun 2018.

c) Rata-rata DER perusahaan indeks SRI-Kehati selama periode penelitian sebesar 1,2334\%. Niai terendah DER adalah sebesar 0,16\% dimiliki oleh PP London Sumatera Tbk tahun 2017. Serta nilai tertinggi adalah sebesar 5,67\% dimiliki PT Adhi Karya Tbk tahun 2012.

d) Rata-rata Firm Size perusahaan indeks SRI-Kehati selama periode penelitian sebesar 30,7298. Nilai tertinggi firm size adalah sebesar 33,11 dimiliki oleh PT Astra International Tbk tahun 2018. Serta nilai terendah adalah sebesar 27,68 dimiliki PT Pembangunan Jaya Ancol Tbk tahun 2012.

e)Rata-rata ROA perusahaan indeks SRI-Kehati selama periode penelitian sebesar $0,1067 \%$. Niai tertinggi ROA adalah sebesar $0,48 \%$ dimiliki oleh Perusahaan Gas Negara Tbk tahun 2012. Serta nilai terendah adalah sebesar 0,0035\% dimiliki PT Pembangunan Jaya Ancol tahun 2012. 


\section{Uji Asumsi Klasik}

\section{1) Uji Normalitas}

Tabel 4

Tabel Uji Normalitas Model Regresi I

\begin{tabular}{|c|c|c|}
\hline & & $\begin{array}{c}\text { Unstandardized } \\
\text { Residual }\end{array}$ \\
\hline \multicolumn{2}{|l|}{$\mathrm{N}$} & 112 \\
\hline Normal & Mean & ,0000000 \\
\hline \multirow[t]{2}{*}{ Parameters ${ }^{a, b}$} & Std. & \\
\hline & Deviation &, $6 / 922929$ \\
\hline Most Extreme & Absolute & 080 \\
\hline \multirow[t]{2}{*}{ Differences } & Positive & ,080 \\
\hline & Negative &,- 074 \\
\hline \multicolumn{2}{|l|}{ Test Statistic } &, 080 \\
\hline \multicolumn{2}{|c|}{ Asymp. Sig. (2-tailed) } &, $077^{c}$ \\
\hline
\end{tabular}

Tabel 5

Tabel Uji Normalitas Model Regresi II

\begin{tabular}{|ll|r|}
\hline & & $\begin{array}{r}\text { Unstandardized } \\
\text { Residual }\end{array}$ \\
\hline $\mathrm{N}$ & Mean & 112 \\
Normal & Std. &, 0000000 \\
Parameters & , b &, 30726401 \\
& Deviation &, 070 \\
Most Extreme & Absolute &, 070 \\
Differences & Positive &,- 047 \\
& Negative &, 070 \\
Test Statistic & &, $200^{c, d}$ \\
\hline
\end{tabular}

Sumber : Output data penelitian, diolah

Berdasarkan tabel 3 dan tabel 4 menunjukkan hasil bahwa seluruh data telah terdistribusi secara normal karena memenuhi asumsi normalitas, dimana probabilitas signifikansi yang dihasilkan lebih besar dari $\alpha=0,05$.

2) Uji Multikolinieritas

Tabel 6

Uji Multikolinieritas

\begin{tabular}{|l|l|l|l|l|}
\hline \multirow{2}{*}{ Variabel } & \multicolumn{2}{c|}{ Regresi I } & \multicolumn{2}{c|}{ Regresi II } \\
\cline { 2 - 5 } & Tolerance & VIF & Tolerance & VIF \\
\hline CR & 0,708 & 1,412 & 0,552 & 1,812 \\
\hline DER & 0,719 & 1,391 & 0,469 & 2,131 \\
\hline Firm Size & 0,982 & 1,018 & 0,824 & 1,214 \\
\hline ROA & & & 0,648 & 1,543 \\
\hline
\end{tabular}

Sumber : Output data penelitian, diolah

Berdasarkan tabel 5 menunjukkan bahwa Nilai VIF pada semua variabel regresi I dan regresi II menunjukkan hasil VIF lebih kecil dari 10. Selain itu nilai Tolerance juga menunjukkan hasil lebih kecil dari 1 . Hal ini berarti bahwa model regresi tidak memiliki masalah multikolonieritas data. 
3) Uji Autokorelasi

Tabel 7

Hasil Uji Autokorelasi

\begin{tabular}{|l|l|l|l|l|}
\hline Model & $\mathrm{dU}$ & $\mathrm{dW}$ & $4-\mathrm{dU}$ & Keterangan \\
\hline Regresi I & 1,7472 & 2,009 & 2,252 & Bebas Autokorelasi \\
\hline Regresi II & 1,7664 & 1,937 & 2,063 & Bebas Autokorelasi \\
\hline
\end{tabular}

Sumber : Output data penelitian, diolah

Berdasarkan hasil analisis regresi diperoleh nilai dengan syarat bahwa angka dW berada di antara dU dan 4-dU pada regresi I dan regresi II maka hasil tersebut dapat dinyatakan tidak terjadi autokorelasi.

4) Uji Heteroskedastisitas

Gambar 1

Uji Heteroskedastisitas Model Regresi I

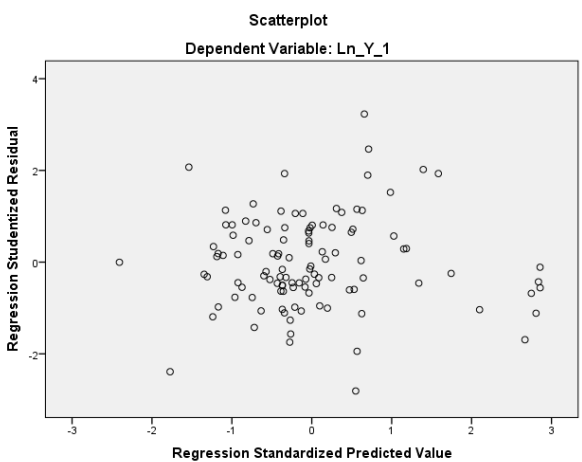

Gambar 2

Uji Heteroskedastisitas Model Regresi II

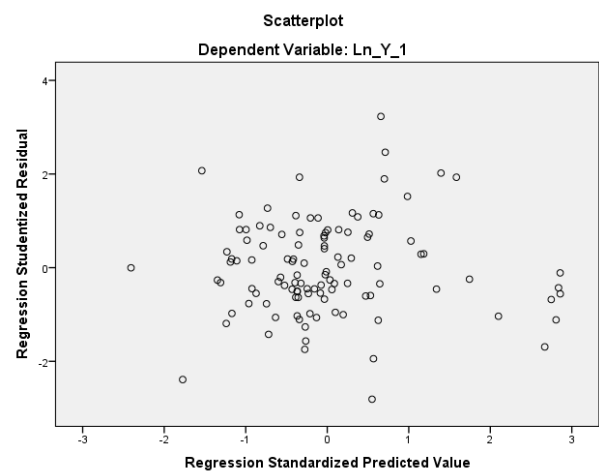

Sumber : Output data penelitian, diolah

Berdasarkan gambar 1 dan gambar 2 terlihat bahwa titik menyebar secara acak, baik di bagian atas angka nol maupun bawah angka nol dari sumbu vertikal. Pola scatterplot membentuk pola yang acak serta data mampu dilihat menyebar secara merata, sehingga bisa disimpulkan bahwa regresi I dan regresi II dinyatakan tidak terjadi heteroskedastisitas. 


\section{Uji Hipotesis}

\section{Uji Statistik F}

Tabel 8

Hasil Uji Statistik F Regresi I

\begin{tabular}{|ll|r|r|r|r|r|}
\hline \multicolumn{7}{|c|}{ MNOVA $^{\mathrm{a}}$} \\
\hline 1 & Sum of Squares & \multicolumn{1}{c|}{ df } & Mean Square & \multicolumn{1}{c|}{ F } & Sig. \\
\hline & Regression & 15,218 & 3 & 5,073 & 15,229 &, $000^{\mathrm{b}}$ \\
& Residual & 35,640 & 107 &, 333 & & \\
& Total & 50,858 & 110 & & & \\
\hline
\end{tabular}

a. Dependent Variable: Ln_Z_2

b. Predictors: (Constant), Ln_X3_2, Ln_X2_2, Ln_X1_2

Sumber : Output data penelitian, diolah

Berdasarkan hasil tabel diatas diperoleh nilai $\mathrm{F}$ sebesar 15,229 dengan signifikansi sebesar 0,000. Hasil tersebut berarti terdapat pengaruh signifikan secara simultan antara variabel independen terhadap variabel dependen karena nilai signifikansi 0,000 lebih kecil dari 0,05.

Tabel 9

\section{Hasil Uji Statistik F Regresi II}

\begin{tabular}{|ll|r|r|r|c|c|}
\hline \multicolumn{7}{|c|}{ MNOVA $^{\mathrm{a}}$} \\
\hline 1 & Sum of Squares & \multicolumn{1}{c|}{ df } & Mean Square & F & \multicolumn{1}{l|}{ Sig. } \\
\hline & Regression & 1,679 & 4 &, 420 & 4,790 &, $001^{b}$ \\
& Residual & 9,288 & 106 &, 088 & & \\
& Total & 10,967 & 110 & & & \\
\hline
\end{tabular}

a. Dependent Variable: Ln_Y_1

b. Predictors: (Constant), Ln_Z_1, Ln_X1_1, Ln_X3_1, Ln_X2_1

Sumber : Output data penelitian, diolah

Berdasarkan hasil tabel diatas diperoleh nilai $\mathrm{F}$ sebesar 4,790 dengan signifikansi sebesar 0,000. Hasil tersebut berarti terdapat pengaruh signifikan secara simultan antara variabel independen terhadap variabel dependen karena nilai signifikansi 0,000 lebih kecil dari 0,05.

Uji Koefisien Determinasi $\left(\mathrm{R}^{2}\right)$

Tabel 10

Hasil Uji Koefisien Determinasi Regresi I

\begin{tabular}{|l|r|r|r|r|r|}
\hline Model & $\mathrm{R}$ & $\mathrm{R}$ Square & \multicolumn{1}{c|}{$\begin{array}{c}\text { Adjusted R } \\
\text { Square }\end{array}$} & $\begin{array}{l}\text { Std. Error of the } \\
\text { Estimate }\end{array}$ & Durbin-Watson \\
\hline 1 &, $547^{\mathrm{a}}$ &, 299 &, 280 &, 57713 & 2,009 \\
\hline
\end{tabular}

a. Predictors: (Constant), Ln_X3_2, Ln_X2_2, Ln_X1_2

b. Dependent Variable: Ln_Z_2

Sumber : Output data penelitian, diolah 
Tabel 9 menunjukkan nilai $\mathrm{R}^{2}$ adalah sebesar 0,299 yang berarti bahwa variasi pada variabel independen mampu menjelaskan 29,9\% variasi variabel dependen. Sedangkan sisanya 70,1\% dijelaskan oleh variabel lain diluar variabel independen.

Tabel 11

Hasil Uji Koefisien Determinasi Regresi II

\begin{tabular}{|l|r|r|r|r|r|}
\hline Model & $\mathrm{R}$ & $\mathrm{R}$ Square & \multicolumn{1}{c|}{$\begin{array}{c}\text { Adjusted R } \\
\text { Square }\end{array}$} & $\begin{array}{l}\text { Std. Error of the } \\
\text { Estimate }\end{array}$ & Durbin-Watson \\
\hline 1 &, $391^{\mathrm{a}}$ &, 153 &, 121 &, 29602 & 1,937 \\
\hline
\end{tabular}

a. Predictors: (Constant), Ln_Z_1, Ln_X1_1, Ln_X3_1, Ln_X2_1

b. Dependent Variable: Ln_Y_1

Sumber : Output data penelitian, diolah

Tabel 10 menunjukkan bahwa nilai R2 adalah sebesar 0,153 yang berarti bahwa variasi pada variabel independen mampu menjelaskan $15,3 \%$ variasi variabel dependen. Sedangkan sisanya $84,7 \% \%$ dijelaskan oleh variabel lain diluar variabel independen.

\section{Uji Statistik T}

Tabel 12

Hasil Uji T Regresi I

\begin{tabular}{|c|c|c|c|c|c|c|}
\hline \multirow{2}{*}{\multicolumn{2}{|c|}{ Model }} & \multicolumn{2}{|c|}{$\begin{array}{c}\text { Unstandardized } \\
\text { Coefficients }\end{array}$} & \multirow{2}{*}{$\begin{array}{c}\text { Standardized } \\
\text { Coefficients } \\
\text { Beta }\end{array}$} & \multirow[b]{2}{*}{$\mathrm{t}$} & \multirow[b]{2}{*}{ Sig. } \\
\hline & & B & Std. Error & & & \\
\hline \multirow[t]{4}{*}{1} & (Constant) & $-17,162$ & 3,336 & & $-5,144$ & ,000 \\
\hline & Ln_X1_2 &,- 412 & ,158 &,- 251 & $-2,612$ & ,010 \\
\hline & Ln_X2_2 &,- 561 & ,125 &,- 427 & $-4,476$ & ,000 \\
\hline & Ln_X3_2 & 9,944 & 2,072 & ,392 & 4,798 &, 000 \\
\hline
\end{tabular}

a. Dependent Variable: Ln_Z_2

Sumber : Output data penelitian, diolah

Tabel 13

Hasil Uji T Persamaan Regresi II

\begin{tabular}{|c|c|c|c|c|c|c|}
\hline \multirow{2}{*}{\multicolumn{2}{|c|}{ Model }} & \multicolumn{2}{|c|}{$\begin{array}{c}\text { Unstandardized } \\
\text { Coefficients }\end{array}$} & \multirow{2}{*}{$\begin{array}{c}\text { Standardized } \\
\text { Coefficients } \\
\text { Beta }\end{array}$} & \multirow[b]{2}{*}{$\mathrm{t}$} & \multirow[b]{2}{*}{ Sig. } \\
\hline & & $\mathrm{B}$ & Std. Error & & & \\
\hline \multirow[t]{5}{*}{1} & (Constant) & 5,738 & 2,692 & & 2,131 & ,035 \\
\hline & Ln_X1_1 & ,071 & ,058 & ,148 & 1,231 & ,221 \\
\hline & Ln_X2_1 & ,127 & ,039 & ,423 & 3,245 & ,002 \\
\hline & Ln_X3_1 & $-1,157$ &, 584 &,- 195 & $-1,980$ & ,050 \\
\hline & Ln_Z_1 & ,133 & ,034 & ,430 & 3,871 & ,000 \\
\hline
\end{tabular}

a. Dependent Variable: Ln_Y_1

Sumber : Output data penelitian, diolah. 
Pengujian hipotesis pertama menunjukkan bahwa hipotesis pertama dapat diterima. Hal ini mengacu pada hasil uji $\mathrm{T}$ yang menunjukkan bahwa $\mathrm{CR}$ berpengaruh negatif signifikan terhadap ROA dengan probabilitas signifikansi sebesar 0,010. Berdasarkan analisis du-pont system, salah satu pembentuk ROA adalah aktiva lancar. Jika aktiva lancar semakin tinggi, maka berarti banyak aktiva lancar yang mengendap dan tidak digunakan untuk meningkatkan profitabilitas perusahaan melalui investasi. Hasil ini sejalan dengan penelitian yang dilakukan oleh (Nursatyani et al., 2014).

Pengujian hipotesis kedua menunjukkan bahwa hipotesis kedua dapat diterima. Hal ini mengacu pada hasil uji $\mathrm{T}$ yang menunjukkan bahwa DER berpengaruh negatif dan signifikan terhadap ROA dengan probabilitas signifikansi sebesar 0,00. Mengacu pada pecking order theory. Perusahaan akan menggunakan hutang sebagai pilihan terakhir sumber modal, namun hal tersebut hanya berlaku untuk perusahaan yang kruang profitable (Sudarsono \& Sudiyatno, 2016). Liabiltias semakin tinggi, maka berarti semakin besar kemungkinan kegagalan bayar perusahaan sehingga berdampak pada menurunnya ROA. Hasil ini sejalan dengan penelitian yang dilakukan oleh (Putra \& Badjra, 2015).

Pengujian hipotesis ketiga menunjukkan bahwa hipotesis ketiga dapat diterima. Hal ini mengacu pada hasil uji $\mathrm{T}$ yang menunjukkan bahwa firm size berpengaruh positif signifikan terhadap ROA dengan probabilitas signifikansi sebesar 0,00. Berdasarkan cyclical theory, peningkatan firm size akan meningkatkan ROA sampai suatu titik maka peningkatan tersebut akan menurunkan ROA. Perusahaan berukuran besar pasti menghasilkan penjualan yang lebih besar serta laba bersih yang semakin tinggi, sehingga meningkatkan ROA. Hasil ini sejalan dengan penelitian yang dilakukan oleh (Barus, 2013).

Pengujian hipotesis keempat menunjukkan bahwa hipotesis keempat ditolak. Hal ini mengacu pada hasil uji $\mathrm{T}$ yang menunjukkan bahwa $\mathrm{CR}$ berpengaruh positif dan tidak signifikan terhadap return saham dengan probabilitas signifikansi sebesar 0,221. Berdasarkan signalling theory, sinyal dari perusahaan akan ditangkap oleh pihak eksternal. CR yang semakin tinggi berpengaruh meningkatnya return saham, namun tidak signifikan sebagai pembentuk return saham. Hasil ini sejalan dengan penelitian yang dilakukan oleh (Kennedy \& Angriawan, 2015).

Pengujian hipotesis kelima menunjukkan bahwa hipotesis kelima dapat diterima. Hal ini mengacu pada hasil uji T yang menunjukkan bahwa DER berpengaruh positif dan signifikan terhadap return saham dengan probabilitas signifikansi sebesar 0,002. Berdasarkan pecking order theory, perusahaan menggunakan hutang sebagai sumber modal terakhir dan untuk perusahaan yang cenderung kurang profitable. Mengacu pada signalling theory, hutang yang dilakukan perusahaan berdampak positif karena meningkatnya hutang berarti meningkatnya risiko. Risiko yang semakin tinggi akan berdampak pada return saham yang semakin tinggi juga. Sehingga DER bisa berdampak positif pada return saham. Hasil ini sejalan dengan penelitian yang dilakukan oleh (Kennedy \& Angriawan, 2015).

Pengujian hipotesis keenam menunjukkan bahwa hipotesis keenam ditolak. Hal ini mengacu pada hasil uji $\mathrm{T}$ yang menunjukkan bahwa firm size berpengaruh negatif dan tidak signifikan terhadap return saham dengan probabilitas signifikansi sebesar 0,050. Berdasarkan fama-french three factor model, firm size memiliki hubungan negatif terhadap return saham. Firm size yang semakin tinggi berpengaruh terhadap menurunnya return saham, serta sebaliknya. Hasil ini sejalan dengan penelitian yang dilakukan oleh (Chandra et al., 2019).

Pengujian hipotesis ketujuh menunjukkan bahwa hipotesis ketujuh diterima. Hal ini mengacu pada hasil uji $\mathrm{T}$ yang menunjukkan bahwa ROA berpengaruh positif dan signifikan terhadap return saham dengan probabilitas signifikansi sebesar 0,00. Berdasarkan signalling theory, sinyal dari perusahaan akan ditangkap oleh pihak eksternal. ROA yang semakin tinggi berpengaruh meningkatnya return saham. Hasil ini sejalan dengan penelitian yang dilakukan oleh (Chandra et al., 2019). 
Pengujian hipotesis kedelapan menunjukkan bahwa hipotesis kedelapan ditolak. Hal ini berdasarkan hasil pengujian Sobel Test menunjukkan nilai $t$ hitung $=-2,11793$ lebih rendah dari t tabel dengan tingkat signifikansi 0,05 yaitu 1,96 maka dapat disimpulkan bahwa tidak ada pengaruh mediasi. Berdasarkan Signalling Theory, CR yang berpengaruh negatif terhadap return saham berarti sinyal negatif untuk investor. Hal tersebut akan direspons sebagai suatu sinyal negatif oleh investor dengan menurunnya permintaan saham oleh investor.

Pengujian hipotesis ketujuh menunjukkan bahwa hipotesis kesembilan ditolak. Hal ini berdasarkan hasil pengujian Sobel Test menunjukkan nilai t hitung $=-2,887312$ lebih rendah dari $\mathrm{t}$ tabel dengan tingkat signifikansi 0,05 yaitu 1,96 maka dapat disimpulkan bahwa tidak ada pengaruh mediasi. Berdasarkan Pecking Order Theory, perusahaan lebih memilih menggunakan laba ditahan sebagai pilihan pertama untuk sumber modal. Namun, perusahaan yang kurang profitable cenderung menggunakan hutang sebagai sumber modal. Hutang yang tinggi akan berpengaruh terhadap menurunnya ROA. Namun, investor mungkin menggunakan rasio profitabilitas lain untuk mempertimbangkan return saham. Hasil ini mendukung penelitian dari (Antariksa \& Sudiartha, 2019).

Pengujian hipotesis kesepuluh menunjukkan bahwa hipotesis kesepuluh dapat diterima. Hal ini berdasarkan hasil pengujian Sobel Test menunjukkan nilai t hitung $=52,478206$ lebih besar dari t tabel dengan tingkat signifikansi 0,05 yaitu 1,96 maka dapat disimpulkan bahwa ada pengaruh mediasi. Berdasarkan Signalling Theory, dimana semakin tinggi firm size berarti kinerja perusahaan dalam memperoleh laba semakin baik. Hal tersebut akan direspons sebagai suatu sinyal positif oleh investor dengan adanya permintaan saham perusahaan yang mengalami peningkatan menyebabkan harga saham naik. Harga saham yang meningkat akan meningkatkan return saham.

\section{PENUTUP}

Tujuan dari dilakukannya penelitian ini adalah untuk menganalisis pengaruh current ratio, debt to equity ratio, serta firm size terhadap return saham dengan ROA sebagai variabel intervening. Variabel independent yang digunakan adalah current ratio, debt to equity ratio, serta firm size. Variabel intervening yang digunakan adalah return on asset. Sedangkan variabel dependen yang digunakan adalah return saham.

Berdasarkan hasil penelitian yang telah dilakukan dapat disimpulkan bahwa CR dan DER memiliki pengaruh negatif dan signifikan terhadap ROA, sedangkan firm size memiliki pengaruh positif dan signifikan terhadap ROA. Selain itu, CR berpengaruh positif tidak signifikan terhadap return saham. DER dan ROA berpengaruh positif signifikan terhadap return saham, namun firm size berpengaruh negatif tidak signifikan terhadap return saham. Hasil Uji Sobel menunjukkan bahwa ROA dapat memediasi hubungan antara Firm Size terhadap Return Saham. Namun, tidak mampu memediasi hubungan antara CR dan DER terhadap return saham. Karena itu sebelum melakukan investasi investor disarankan untuk memperhatikan ukuran perusahaan untuk memperoleh return yang optimal, sedangkan untuk perusahaan disarankan lebih meningkatkan ROA agar semakin banyak investor yang tertarik menanamkan sahamnya di perusahaan tersebut.

Keterbatasan dalam penelitian ini adalah terdapat beberapa rasio keuangan yang ternyata tidak berpengaruh sebagai prediktor return saham. Serta, variabel independen yang digunakan adalah hanya satu dari beberapa rasio keuangan. Selanjutnya, tingkat ROA perusahaan terdaftar dalam indeks SRI-Kehati cukup rendah. Berikutnya, kurangnya penelitian yang mampu membandingkan hasil penelitian pada indeks SRI-Kehati. 


\section{DAFTAR PUSTAKA}

Agus, S. (2010). Manajemen Keuangan Teori dan Aplikasi. Edisi Keempat. Yogyakarta: BPFE.

Arista, D., \& Astohar, A. (2012). Analisis Faktor-Faktor Yang Mempengaruhi Return Saham. Jurnal Ilmu Manajemen Dan Akuntansi Terapan (JIMAT), 3(1).

Barus, A. C. (2013). Analisis Faktor-Faktor yang Mempengaruhi Profitabilitas pada Perusahaan Manufaktur yang Terdaftar di Bursa Efek Indonesia. Jurnal Wira Ekonomi Mikroskil: JWEM, 3(2), 111-121.

Brigham, E. F., \& Houston, J. F. (2010). Essentials of financial management. Engage Learning Asia.

Chandra, T., Junaedi, A. T., Wijaya, E., Suharti, S., Mimelientesa, I., \& Ng, M. (2019). The effect of capital structure on profitability and stock returns: Empirical analysis of firms listed in Kompas 100. Journal of Chinese Economic and Foreign Trade Studies.

Cindy Ardina Antariksa, N. M., \& Sudiartha, G. M. (2019). PERAN PROFITABILITAS MEMEDIASI PENGARUH LIKUIDITAS DAN STRUKTUR MODAL TERHADAP RETURN SAHAM. E-Jurnal Manajemen; Vol 8 No 6 (2019)DO 10.24843/EJMUNUD.2019.V08.I06.P01 . Retrieved from https://ojs.unud.ac.id/index.php/Manajemen/article/view/45503

Dewi, P. E. D. M. (2017). Pengaruh Rasio Likuiditas, Profitabilitas, Solvabilitas, Aktivitas Dan Penilaian Pasar Terhadap Return Saham. JIA (Jurnal Ilmiah Akuntansi), 1(2).

Fahmi, I. (2011). Analisis laporan keuangan. Bandung: Alfabeta.

Hartono, J. (2013). Teori Portofolio dan Analisis Investasi Edisi Kedelapan. Yogyakarta: BPFE.

Horne, J. C. Van, \& Wachowicz Jr, J. M. (2012). Prinsip-prinsip Manajemen Keuangan (Edisi 13). Jakarta: Salemba Empat.

Kennedy, P. S. J., \& Angriawan, D. P. (2015). PENGARUH CR, DER, DAN SUKU BUNGA TERHADAP RETURN SAHAM STUDI KASUS PADA PERUSAHAAN SUBSEKTOR TRANSPORTASI. Buletin Ekonomi, 19(2), 11-22.

Kurniawan, T., Ghasarma, R., \& Yuliani. (2016). Pengaruh likuiditas, financial leverage , aktivitas terhadap return saham dengan profitabilitas sebagai variabel mediasi. Jurnal Manajemen Dan Bisnis Sriwijaya, 14(1), 121-132.

Lindayani, N. W., \& Dewi, S. K. S. (2016). Dampak Struktur Modal Dan Inflasi Terhadap Profitabilitas Dan Return Saham Perusahaan Keuangan Sektor Perbankan. E-Jurnal Manajemen Universitas Udayana, 5(8).

Mohamad, N. E. A. B., \& Saad, N. B. M. (2010). Working capital management: The effect of market valuation and profitability in Malaysia. International Journal of Business and Management, 5(11), 140.

Nursatyani, A., Wahyudi, S., \& Syaichu, M. (2014). NALISIS PENGARUH CURRENT RATIO, FIRM SIZE, DAN ASSETS TANGIBILITY TERHADAP RETURN ON ASSET DENGAN DEBT TO TOTAL ASSET SEBAGAI VARIABEL INTERVENING (Studi pada Perusahaan Sektor Pertambangan yang Terdaftar di BEI Tahun 2008-2011). Jurnal Bisnis Strategi, 23(2), 97-127.

Parwati, R. R. A. D., \& Sudiartha, G. M. (2016). Pengaruh profitabilitas, leverage, likuiditas dan penilaian pasar tehadap return saham perusahaan manufaktur. E-Jurnal Manajemen Universitas Udayana, 5(1).

Pramesti, D., Wijayanti, A., \& Nurlaela, S. (2016). Pengaruh Rasio Likuiditas, Leverage, Aktivitas Dan Firm Size Terhadap Profitabilitas Perusahaan Sub Sektor Otomotif Dan Komponen Di Bursa Efek Indonesia.

Pratiwi, N. P. T. W., \& Putra, I. W. (2015). Pengaruh rasio keuangan, ukuran perusahaan, arus 
kas aktivitas operasi pada return saham. E-Jurnal Akuntansi Universitas Udayana, 11(2), 531-546.

Putra, A. A. W. Y., \& Badjra, I. B. (2015). Pengaruh leverage, pertumbuhan penjualan dan ukuran perusahaan terhadap profitabilitas. E-Jurnal Manajemen Universitas Udayana, 4(7).

Putra, I. M. G. D., \& Dana, I. M. (2016). Pengaruh profitabilitas, leverage, likuiditas dan ukuran perusahaan terhadap return saham perusahaan farmasi di BEI. E-Jurnal Manajemen Universitas Udayana, 5(11).

Raningsih, N. K., \& Putra, I. M. P. D. (2015). Pengaruh rasio-rasio keuangan dan ukuran perusahaan pada return saham. E-Jurnal Akuntansi Universitas Udayana, 13(2), 582-598.

RIAWAN, R. (2019). Debt to Equity Ratio (DER) dan Ukuran Perusahaan yang di Mediasi oleh Return on Assets (ROA) Terhadap Return Saham.

Rizal, M. (2016). Analisis Pengaruh Profitabilitas dan Likuiditas Terhadap Return Saham Syariah dengan Risiko Investasi Sebagai Variabel Intervening ( Studi Empiris pada Perusahaan Tambang yang terdaftar di Daftar Efek Syariah periode 2012-2014 ) The Analysis Effect of Pro. Jurnal Univ Jember.

Rosanti, W. (n.d.). DETERMINAN RETURN SAHAM PADA INDEKS SRI- KEHATI DI BURSA EFEK INDONESIA. 1-21.

Rosyadah, F. (2013). Pengaruh Struktur Modal Terhadap Profitabilitas (Studi Pada Perusahaan Real Estate and Property Yang Terdaftar di Bursa Efek Indonesia (BEI) Periode 20092011). Jurnal Administrasi Bisnis, 3(2).

Santa, S., \& Muharam, H. (2015). Analisis Pengaruh Volatilitas Harga, Likuiditas Saham, Eps, Size Firm, Momentum Overnight Terhadap Return Saham. Diponegoro Journal of Management, 4(2003), 1-12. Retrieved from http://ejournal-s1.undip.ac.id/index.php/dbr

Sudarsono, B., \& Sudiyatno, B. (2016). Faktor-Faktor Yang Mempengaruhi Return Saham Pada Perusahaan Property Dan Real Estate Yang Terdaftar Pada Bursa Efek Indonesia Tahun 2009 S/D 2014. Jurnal Bisnis Dan Ekonomi, 23(1).

Sugiarto, A. (2011). Analisa pengaruh beta, size perusahaan, DER dan PBV ratio terhadap return saham. Jurnal Dinamika Akuntansi, 3(1).

Syafri, H. S. (2009). Analisis Kritis atas Laporan Keuangan Edisi Ke satu. PT. Raja Grafindo Persada, Jakarta.

Yuliani, Y., Kurniawan, T., \& Ghasarma, R. (2016). Pengaruh likuiditas, financial leverage, aktivitas terhadap return saham dengan profitabilitas sebagai variabel mediasi. Jurnal Manajemen Dan Bisnis Sriwijaya, 14(1), 121-132. 